\title{
Prevalensi Gangguan Pemusatan Perhatian dan Hiperaktivitas pada Siswa dan Siswi Sekolah Dasar Negeri Kecamatan Padang Timur Kota Padang Tahun 2013
}

\author{
Dita Eka Novriana, Amel Yanis, Machdawaty Masri
}

\begin{abstract}
Abstrak
Gangguan Pemusatan Perhatian dan Hiperaktivitas (GPPH) adalah salah satu masalah psikiatri utama yang sering ditemukan pada anak. Gangguan ini dapat dijumpai pada kehidupan sehari - hari, terutama pada anak usia prasekolah dan usia sekolah. Gangguan ini adalah alasan utama orangtua membawa anaknya berkonsultasi ke psikiater. Penelitian ini bertujuan untuk mengetahui prevalensi GPPH pada siswa dan siswi sekolah dasar negeri Kecamatan Padang Timur Tahun 2013. Penelitian ini bersifat deskriptif dan sampel diambil secara proportional stratified random sampling di empat sekolah dasar negeri dengan jumlah sampel 80 orang dan yang memenuhi kriteria inklusi berjumlah 75 orang yang terdiri dari 38 orang laki - laki dan 37 orang perempuan. Instrumen penelitian yang digunakan adalah kuesioner Conner's Abreviated Parent - Teacher Rating Scale dan hasil yang didapatkan disajikan dalam bentuk tabel distribusi frekuensi. Hasil penelitian ini menunjukkan bahwa prevalensi GPPH di Kecamatan Padang Timur sebesar 8\%. Perbandingan GPPH pada anak laki - laki dibandingkan anak perempuan 2 : 1. Gejala GPPH terbanyak ditunjukkan pada kategori usia $11-13$ tahun dan berada pada tingkatan kelas 5 . GPPH tipe predominan hiperaktivitas - impulsivitas berjumlah lebih banyak bila dibandingkan dengan tipe predominan inatensi. Anak - anak dengan GPPH membutuhkan perhatian yang lebih dari orang tua dan guru. Hal ini agar kemampuan dan potensi anak tersebut dapat berkembang dengan optimal.
\end{abstract}

Kata kunci: Gangguan Pemusatan Perhatian dan Hiperaktivitas, GPPH, prevalensi

\begin{abstract}
Attention Deficit Hyperactivity Disorder $(A D H D)$ is one of the main problem in psychiatric which is often found in children. This disorder can be found in daily life, especially in preschoolers and school-ages. This disorder is the main reason for the parents taking their children consult to a psychiatrist.The aim of this study is for knowing the prevalence of $A D H D$ in primary school boys and girls at East District of Padang City in 2013. This is a descriptive study and samples were taken by proportional stratified random sampling at four of state primary schools with the total 80 persons. The inclusion criteria was accomplished by 75 persons consisting of 38 boys and 37 girls. Instrument of this study is Conner's Abreviated Parent - Teacher Rating Scale questionnaire and the result is presented in frequency distribution table. The study shows that prevalence of $A D H D$ in East District of Padang is $8 \%$. The ratio between boys and girls is $2: 1$. ADHD's symptomp mostly found in the range of age $11-13$ years old and also in the 5th grade of primary school. ADHD predominant type of hyperactivity - impulsivity is more than predominant type of inattentivity. The children with $A D H D$ need more attention from parents and also the teacher. The purpose is to maximize the existing ability and potential.
\end{abstract}

Keywords:Attention Deficit Hyperactivity Disorder, $A D H D$, prevalence

Affiliasi penulis : Fakultas Kedokteran Universitas Andalas,

Korespondensi : Dita Eka Novriana, email : ditanovriana@gmail.com, Telp/hp: 081365740527

\section{PENDAHULUAN}

Gangguan Pemusatan Perhatian dan Hiperaktivitas (GPPH) atau dalam istilah kedokteran lebih dikenal dengan singkatan ADHD (Attention Deficit Hyperactivity Disorder) adalah salah satu masalah psikiatri utama yang sering ditemukan pada anak. ${ }^{1}$ Gangguan ini dapat dijumpai dalam kehidupan sehari - hari, baik pada anak usia prasekolah, remaja, bahkan dewasa dapat mengalami gangguan ini. Sebagian besar masyarakat, baik dalam lingkungan keluarga, sekolah, dan klinik, masih belum mengenali adanya gangguan ini. Mereka bahkan menganggap gangguan ini sebagai atensi yang kurang baik yang tidak dapat diterima oleh lingkungannya. GPPH ini menjadi salah satu alasan terbesar orang tua untuk membawa anaknya berkonsultasi dengan psikiater. Mayoritas dari para orang tua tersebut mengeluhkan anaknya nakal, tidak mau belajar, tidak bisa diam, cepat beralih perhatian, baik di rumah maupun di sekolah. $^{2}$

Anak dengan GPPH menunjukkan beberapa gejala utama, seperti aktivitas yang berlebihan, tidak bisa diam, senantiasa bergerak, tidak dapat memusatkan perhatian, dan impulsif. Gangguan ini merupakan gangguan biologis pada otak yang berlangsung secara kronis sehingga mengakibatkan terganggunya fungsi kognitif. Manifestasi yang sering timbul akibat terganggunya fungsi kognitif ini diantaranya adalah menurunnya derajat intelegensi anak, menurunnya prestasi belajar, pengamatan waktu yang kurang baik, menurunnya daya ingat, baik verbal maupun non-verbal, kurang mampu membuat perencanaan, kurang peka terhadap kesalahan, dan kurang mampu mengarahkan perilaku yang bertujuan. Kelemahan dalam bidang akademik yang sering timbul diantaranya adalah kesulitan membaca, mengeja, berhitung, serta menulis. Gangguan ini juga dapat menimbulkan masalah dalam perkembangan kemampuan berbahasa. Selain itu anak - anak dengan gangguan ini juga kesulitan untuk 
mengendalikan emosi dibandingkan anak normal, mudah mengalami frustasi, dan mudah marah. ${ }^{2}$

Pada umumnya perilaku yang timbul adalah gejala klinis dari GPPH, yakni tidak mampu memusatkan perhatian dan/atau hiperaktivitas atau impulsivitas. Dua gejala tersebut dapat dinilai pada aktivitas anak sehari - hari, baik di rumah maupun di sekolah. Gejala tidak mampu memusatkan perhatian dapat dinilai berdasarkan perilaku anak dalam menyelesaikan tugas, misalnya perhatian anak mudah teralihkan pada beberapa hal, tidak mampu memfokuskan perhatian pada hal - hal kecil, sering membutuhkan pertolongan, membutuhkan waktu yang lama untuk mengerjakan tugas atau mengerjakan hal - hal sederhana, dan sering lalai. Gejala hiperaktivitas/impulsivitas dapat dinilai berdasarkan perilaku seperti tidak bisa duduk tenang, aktivitas yang berlebihan seolah - olah memiliki energi yang berlebihan pula, berlarian kesana kemari, senang memanjat, bicara cepat dan berlebihan, sering menyerobot antrian, dan terlalu cepat menjawab pertanyaan bahkan sebelum pertanyaan yang diberikan kepadanya selesai ditanyakan. ${ }^{2}$

Jika gangguan ini tidak mendapatkan intervensi sejak dini maka dapat menimbulkan masalah psikososial yang lebih buruk, misalnya kesulitan belajar akan berakibat buruk pada prestasi akademik, penyalahgunaan narkotika,alkohol, dan zat adiktif lain, gangguan tingkah laku seperti kenakalan, kekerasan, dan perbuatan kriminal, kesulitan penyesuaian diri, baik di rumah, di sekolah, maupun di masyarakat, serta dapat menimbulkan masalah dalam keluarga. Gangguan ini juga dapat berlanjut ketika dewasa yang dapat menimbulkan masalah dalam penyesuaian diri di lingkungan bekerja ataupun kehidupan berumah tangga. Masalah - masalah psikososial yang akan timbul tersebut juga akan menghambat upaya pembinaan sumber daya manusia di Indonesia. ${ }^{2}$

Berdasarkan Diagnostic and Statistical Manual of Mental Disorder, Edisi ke- $4,{ }^{3}$ awitan terjadinya GPPH ini di bawah usia 7 tahun. Gejala mulai timbul sejak usia dini dengan usia awitan rata - rata $3-4$ tahun. ${ }^{2}$ Gangguan ini dijumpai $2-4$ kali lebih besar pada anak laki - laki dibandingkan anak perempuan. ${ }^{4}$ Angka prevalensi GPPH ini bervariasi tergantung dari instrumen skrining, kriteria diagnosis, serta karakteristik populasi yang diteliti. Di Indonesia, cara untuk mendiagnosis gangguan ini didasarkan pada kriteria diagnosis menurut Pedoman Penggolongan dan Diagnosis Gangguan Jiwa di Indonesia III atau Diagnostic and Statistical Manual of Mental Disorders Edisi IV. Sesuai dengan kriteria DSM IV, prevalensi penderita gangguan ini pada anak usia sekolah sebesar $15,8 \%$ di antara 3006 anak berusia $3-18$ tahun. $^{2}$ Pineda (2001) melaporkan prevalensi gangguan ini terhadap 540 anak berusia $4-17$ tahun di Columbia sebesar $18,2 \%$ untuk anak usia prasekolah, 22,5\% untuk anak usia $6-11$ tahun, dan $7,3 \%$ untuk anak usia $12-17$ tahun. Meskipun banyak penelitian melaporkan angka prevalensi yang berbeda - beda tetapi secara kasar prevalensi untuk gangguan ini adalah sekitar $2 \%-5 \%{ }^{5}$

Angka kejadian yang berbeda juga didapatkan berdasarkan perbedaan jenis kelamin. Anak laki - laki memiliki insiden yang lebih tinggi dibandingkan dengan anak perempuan yaitu sekitar $3-5: 1{ }^{6}$ Menurut hasil survey yang dilakukan oleh National Survey of Children's Health pada tahun 2007 di Amerika Serikat didapatkan prevalensi GPPH untuk anak laki - laki $13,2 \%$ dan untuk anak perempuan $5,6 \%{ }^{7}$. Di Inggris berdasarkan hasil survey didapatkan angka prevalensi GPPH pada anak usia 5 - 15 tahun sekitar 3,62\% untuk anak laki - laki dan 0,85\% untuk anak perempuan. Di Indonesia sendiri dilaporkan angka prevalensi yang juga berbeda antara anak laki laki dan anak perempuan yaitu $35,2 \%$ untuk anak laki - laki dan $18,3 \%$ untuk anak perempuan. ${ }^{2}$

Penelitian mengenai prevalensi GPPH di Indonesia masih sangat sedikit sehingga sampai saat ini belum didapatkan angka pasti mengenai kejadian GPPH di Indonesia. Salah satu data dari unit Psikiatri Anak RSUD Dr. Soetomo, Surabaya, melaporkan 60 kasus GPPH pada tahun 2000 dan 86 kasus pada tahun 2001. Salah satu penelitian yang dilakukan oleh Dwidjo Saputro (2009) pada anak usia sekolah dasar di DKI Jakarta didapatkan angka prevalensi sekitar $26,2 \%{ }^{2}$

Kota Padang terdiri dari beberapa kecamatan dan salah satu kecamatan dengan jumlah sekolah dasar negeri terbanyak berada pada Kecamatan Padang Timur. Adanya jumlah siswa dan siswi sekolah dasar negeri yang besar di Kecamatan Padang Timur ini dapat mendukung untuk ditemukannya anak usia sekolah yang mempunyai gejala GPPH. Hal inilah yang mendorong penulis untuk melakukan penelitian mengenai prevalensi GPPH pada siswa - siswi sekolah dasar negeri di Kecamatan Padang Timur Kota Padang.

\section{METODE}

Penelitian dilaksanakan di sekolah dasar negeri Kecamatan Padang Timur Kota Padang pada Januari 2012 - Maret 2013. Subjek penelitian adalah siswa dan siswi sekolah dasar negeri di Kecamatan Padang Timur Kota Padang. Alasan dipilihnya sekolah dasar negeri dibandingkan sekolah dasar swasta adalah untuk heterogenisasi sampel dan untuk menyingkirkan kemungkinan adanya gangguan lain yang dapat menyertai anak dengan gangguan pemusatan perhatian dan hiperaktivitas. Kriteria inklusi adalah siswa dan siswi kelas $1-6$ SD periode tahun ajaran Juli 2012 - Maret 2013 pada sekolah yang terpilih dalam penelitian, tidak menderita gangguan perkembangan pervasif (termasuk gangguan autisme) dan retardasi mental, dan orangtua siswa dan siswi tersebut menyetujui penelitian ini. Kriteri eksklusi adalah siswa dan siswi yang tidak hadir ketika penelitian ini dilaksanakan. Metode penelitian yang digunakan adalah deskriptif. Sampel dihitung dengan menggunakan rumus :

$$
n=\frac{z_{\alpha}^{2} p q}{d^{2}}
$$

$$
\begin{array}{lc}
\text { Keterangan: } \\
\mathrm{n}: & \text { Jumlah sampel } \\
\mathrm{p}: & \text { Proporsi } 0,05 \\
\mathrm{q}: & (1-\mathrm{P}) \\
\mathrm{d}: & \text { Limit } \\
\end{array}
$$

Berdasarkan rumus di atas didapatkan jumlah sampel sebanyak 73 orang dan dengan memperhitungkan drop out sebanyak $10 \%$ maka jumlah sampel yang terpilih adalah 80 orang. Teknik pengambilan sampel dilakukan secara acak dengan memilih 4 sekolah dasar negeri dari 35 sekolah dasar negeri yang ada di Kecamatan Padang Timur Kota Padang, yaitu SDN 05 
Sawahan, SDN 34 Simpang Haru, SDN 15 Jati Tanah Tinggi, dan SDN 09 Parak Gadang Barat. Jumlah sampel yang telah dihitung berdasarkan rumus akan diambil secara proportional stratified random sampling berdasarkan tingkatan kelas dan jenis kelamin yang tersebar merata di 4 sekolah dasar negeri tersebut. Dari 80 orang sampel, yang memenuhi kriteria inklusi penelitian sebanyak 75 orang. Instrumen penelitian yang digunakan adalah Conner's Abbreviated Parent Teacher Rating Scale. Data yang dikumpulkan adalah data primer yaitu data yang dikumpulkan menggunakan kuesioner yang diisi oleh orang tua dan guru, serta data sekunder adalah data mengenai jumlah sekolah dasar negeri di Kecamatan Padang Timur yang diperoleh dari Dinas Pendidikan Kota Padang dan data jumlah murid di tiap sekolah yang menjadi sampel penelitian ini. Analisis data yang digunakan adalah analisis univariat yang memberikan gambaran mengenai prevalensi Gangguan Pemusatan Perhatian dan Hiperaktivitas.

\section{Hasil Penelitian}

Karakteristik Responden

Tabel 1. Jumlah Total Populasi Siswa dan Siswi di Lokasi Penelitian

\begin{tabular}{clccc}
\hline No. & $\begin{array}{l}\text { Nama } \\
\text { Sekolah }\end{array}$ & Siswa & Siswi & Jumlah \\
\hline 1. & $\begin{array}{l}\text { SDN } 05 \\
\text { Sawahan } \\
\text { SDN 09 }\end{array}$ & 214 & 199 & 413 \\
2. & $\begin{array}{l}\text { Parak } \\
\text { Gadang } \\
\text { Barat } \\
\text { SDN 15 Jati }\end{array}$ & 109 & 90 & 199 \\
3anah \\
$\begin{array}{l}\text { Tinggi } \\
\text { SDN 34 } \\
\text { Simpang } \\
\text { Haru }\end{array}$ & 115 & 110 & 225 \\
4.TAL & 511 & 481 & 992 \\
\hline TOTAL
\end{tabular}

Dari tabel 1 dapat dilihat bahwa jumlah total populasi di tiap - tiap lokasi penelitian berbeda - beda dengan jumlah populasi terbanyak pada SD Negeri 05 Sawahan.

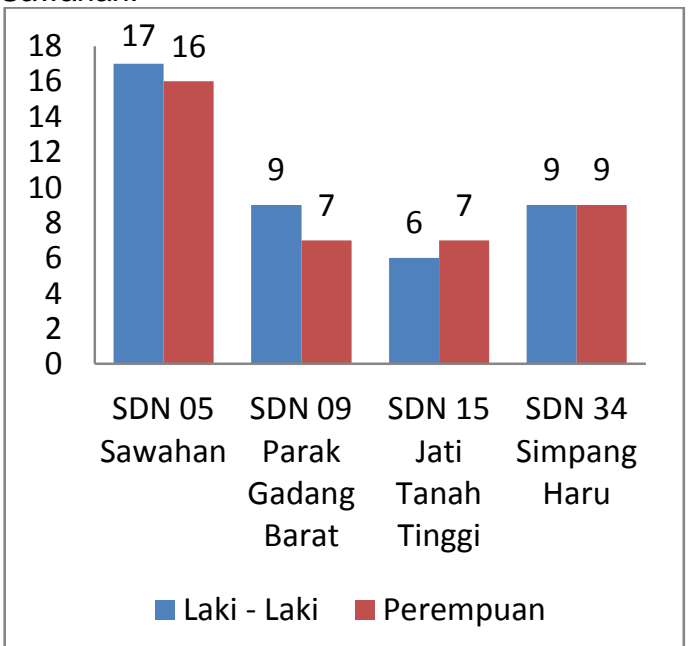

Gambar 1. Distribusi Frekuensi Sampel Penelitian Berdasarkan Jenis Kelamin di Tiap - Tiap
Lokasi Penelitian

Dari gambar 1 terlihat bahwa sebaran jumlah sampel penelitian terbanyak pada SDN 05 Sawahan yaitu 17 orang laki - laki dan 16 orang perempuan.

\section{Prevalensi Gangguan Pemusatan Perhatian dan Hiperaktivitas}

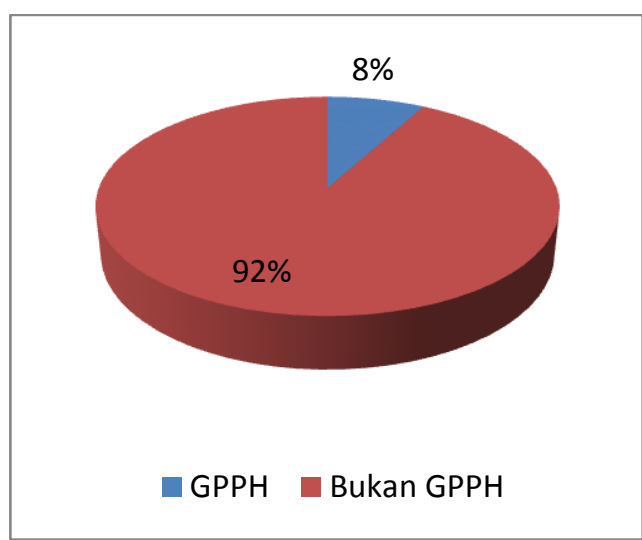

Gambar 2. Prevalensi Gangguan Pemusatan Perhatian dan Hiperaktivitas pada Siswa dan Siswi Sekolah Dasar Negeri Kecamatan Padang Timur Kota Padang Tahun 2013

Dari gambar 2 terlihat bahwa sampel yang menunjukkan adanya gejala gangguan pemusatan perhatian dan hiperaktivitas di sekolah dasar negeri Kecamatan Padang Timur berjumlah 6 orang (8\%).

Prevalensi Gangguan Pemusatan Perhatian dan Hiperaktivitas Berdasarkan Jenis Kelamin

Tabel 2. Prevalensi Gangguan Pemusatan Perhatian dan Hiperaktivitas pada Siswa dan Siswi Sekolah Dasar Negeri Kecamatan Padang Timur Kota Padang Tahun 2013 Berdasarkan Jenis Kelamin

\begin{tabular}{cccc}
\hline No. & $\begin{array}{c}\text { Jenis } \\
\text { Kelamin }\end{array}$ & Jumlah & $\%$ \\
\hline 1. & Laki - Laki & 4 & 66,67 \\
2. & Perempuan & 2 & 33,33 \\
\hline & JUMLAH & 6 & 100 \\
\hline
\end{tabular}

Dari tabel 2 terlihat bahwa gejala gangguan pemusatan perhatian dan hiperaktivitas lebih banyak ditunjukkan pada anak laki - laki dibandingkan anak perempuan.

Prevalensi Gangguan Pemusatan Perhatian dan Hiperaktivitas Berdasarkan Usia

Tabel 3. Prevalensi Gangguan Pemusatan Perhatian dan Hiperaktivitas pada Siswa dan Siswi Sekolah Dasar Negeri Kecamatan Padang Timur Kota Padang Tahun 2013 Berdasarkan Usia

\begin{tabular}{cccc}
\hline No. & \multicolumn{1}{c}{ Usia } & Jumlah & $\%$ \\
\hline 1. & $5-7$ tahun & 1 & 16,67 \\
2. & $8-10$ tahun & 2 & 33,33 \\
3. & $11-13$ tahun & 3 & 50 \\
4. & $>14$ tahun & - & - \\
\hline & JUMLAH & 6 & 100 \\
\hline
\end{tabular}

Dari tabel 3 terlihat bahwa gejala pemusatan perhatian 
dan hiperaktivitas paling banyak ditunjukkan pada kategori usia 11 - 13 tahun (50\%).

Prevalensi Gangguan Pemusatan Perhatian dan Hiperaktivitas Berdasarkan Tingkatan Kelas

Tabel 4. Prevalensi Gangguan Pemusatan Perhatian dan Hiperaktivitas pada Siswa dan Siswi Sekolah Dasar Negeri Kecamatan Padang Timur Kota Padang Tahun 2013 Berdasarkan Tingkatan Kelas

\begin{tabular}{cccc}
\hline No. & $\begin{array}{c}\text { Tingkatan } \\
\text { Kelas }\end{array}$ & Jumlah & $\%$ \\
\hline 1. & Kelas 1 & 1 & 16,67 \\
2. & Kelas 2 & - & - \\
3. & Kelas 3 & 1 & 16,67 \\
4. & Kelas 4 & - & - \\
5. & Kelas 5 & 4 & 66,66 \\
6. & Kelas 6 & - & - \\
\hline & JUMLAH & 6 & 100 \\
\hline
\end{tabular}

Dari tabel 4 terlihat bahwa gangguan pemusatan perhatian dan hiperaktivitas ditunjukkan terbanyak pada tingkatan kelas yang lebih tinggi yaitu pada kelas $5(66,66 \%)$.

\section{Prevalensi Gangguan Pemusatan Perhatian dan Hiperaktivitas Berdasarkan Munculan Gejala Dominan}

Tabel 5. Prevalensi Gangguan Pemusatan Perhatian dan Hiperaktivitas pada Siswa dan Siswi Sekolah Dasar Negeri Kecamatan Padang Timur Kota Padang Tahun 2013 Berdasarkan Munculan Gejala Dominan

\begin{tabular}{cccc}
\hline No. & $\begin{array}{c}\text { Munculan Gejala } \\
\text { Dominan }\end{array}$ & Jumlah & $\%$ \\
\hline 1. & $\begin{array}{c}\text { Tipe Predominan } \\
\text { Inatensi }\end{array}$ & 2 & 33,33 \\
2. & $\begin{array}{c}\text { Tipe Predominan } \\
\text { Hiperaktivitas - } \\
\text { Impulsivitas }\end{array}$ & 4 & 66,67 \\
3. & Tipe Kombinasi & - & 100 \\
\hline & JUMLAH & 6 & 100 \\
\hline
\end{tabular}

Dari tabel 5 terlihat bahwa gejala dominan ditunjukkan terbanyak pada subtipe predominan hiperaktivitas impulsivitas $(66,67 \%)$.

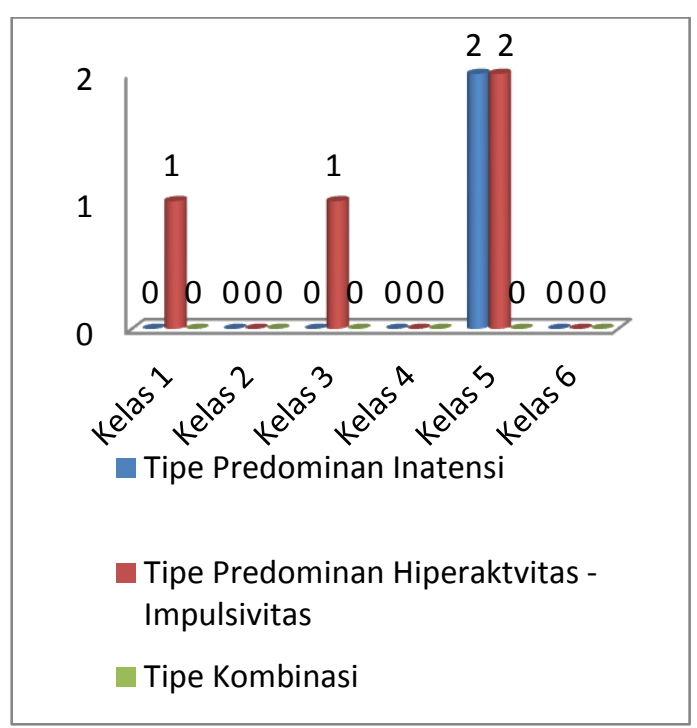

Gambar 3. Prevalensi Subtipe Munculan Gejala Dominan Gangguan Pemusatan Perhatian dan hiperaktivitas pada Siswa dan Siswi Sekolah Dasar
Negeri Kecamatan Padang Timur Kota Padang Tahun 2013

Gambar 3 menunjukkan bahwa subtipe predominan hiperaktivitas - impulsivitas dan subtipe inatensi didapatkan terbanyak pada tingkatan kelas 5 sedangkan pada tingkatan kelas 1 dan 3 hanya didapatkan subtipe predominan hiperaktivitas impulsivitas.

\section{Diskusi}

Dari hasil penelitian ini didapatkan prevalensi Gangguan Pemusatan Perhatian dan Hiperaktivitas (GPPH) sebesar $8 \%$. Hal ini sesuai dengan kisaran angka yang dikemukan oleh para ahli mengenai prevalensi GPPH yaitu 3\% - 10\%. ${ }^{8}$ Angka prevalensi yang didapatkan dari penelitian ini hampir sama dengan kisaran angka yang didapatkan di Kabupaten Bantul 5,37\%, di Thailand $6,5 \%,{ }^{10}$ dan di Nigeria $8,7 \%{ }^{11} \quad$ Hasil yang berbeda didapatkan pada penelitian yang dilakukan oleh Dwidjo Saputro (2009) di sekolah dasar di DKI Jakarta yaitu $26,2 \%$. Perbedaan angka yang besar ini diduga disebabkan oleh perbedaan metode dan instrumen penelitian yang digunakan. Pada penelitian yang dilakukan oleh Dwidjo Saputro (2009) dilakukan beberapa kali penapisan pada sampel. Penelitian tersebut juga bertujuan untuk menguji salah satu instrumen yang dapat digunakan untuk deteksi dini GPPH di Indonesia yaitu instrumen Skala Penilai Perilaku Anak Hiperaktif Indonesia (SPPAHI). Penyusunan instrumen SPPAHI ini disesuaikan dengan kultur budaya masyarakat timur, terutama Indonesia. Penggunaan instrumen SPPAHI ini belum cukup luas digunakan di Indonesia.

Salah satu faktor yang mempengaruhi prevalensi GPPH adalah jenis kelamin. Menurut literatur anak laki - laki memiliki angka kejadian yang lebih besar bila dibandingkan dengan anak perempuan. Perbandingan anak laki - laki yang menderita GPPH dibandingkan dengan anak perempuan berkisar $2: 1-10: 1$ dengan rata - rata sekitar $3-5: 1^{2,6}$ Dari hasil penelitian ini didapatkan bahwa anak laki - laki memiliki angka kejadian yang lebih tinggi bila dibandingkan dengan anak perempuan yaitu $2: 1$. Hal ini dapat disebabkan oleh beberapa hal, salah satunya adalah mekanisme genetik terkait jenis kelamin. Anak laki - laki lebih banyak menunjukkan agresivitas sedangkan anak perempuan lebih banyak menunjukkan kelemahan kognitif sehingga gejala yang tampak lebih nyata ditunjukkan oleh anak laki - laki. ${ }^{12}$

Usia juga merupakan salah satu faktor dalam menentukan prevalensi GPPH. Menurut literatur gejala GPPH terlihat lebih jelas pada anak yang berusia lebih muda yaitu di bawah usia 7 tahun, ${ }^{3}$ dengan usia awitan rata - rata sekitar 3 - 4 tahun. $^{2}$ Dari hasil penelitian ini didapatkan prevalensi terbanyak berada pada kategori usia 11 - 13 tahun yaitu $50 \%$ sedangkan pada kategori usia 8 - 10 tahun didapatkan prevalensi $33,33 \%$ dan pada kategori usia $5-7$ tahun hanya $16,67 \%$. Hal ini menunjukkan angka yang berbeda dari penelitian yang dilakukan oleh Dwidjo Saputro di DKI Jakarta (2009) yang menunjukkan bahwa prevalensi terbanyak berada pada kategori usia $5-7$ tahun yaitu $28,2 \%$, kategori usia 8 - 10 tahun $24,7 \%$, dan kategori usia $11-13$ tahun $25,8 \%{ }^{2}$ Salah satu penelitian yang mendapatkan hasil yang sama dilakukan oleh Tanya E. Froehlich, et al (2007) di Amerika Serikat pada anak usia 8 - 15 tahun menunjukkan prevalensi yang lebih 
besar pada anak kategori usia 12 - 15 tahun (52,5\%) dibandingkan pada anak kategori usia 8 - 11 tahun $(47,5 \%)^{13}$ Gejala GPPH lebih dominan ditunjukkan pada anak usia di bawah 7 tahun dan semakin berkurang berdasarkan peningkatan usia. ${ }^{2}$ Sebagian besar orang tua dan guru berpendapat bahwa gejala GPPH ini cukup lazim ditemukan pada anak yang berusia lebih muda sehingga dianggap kondisi yang normal. Ketika gejala ini ditemukan pada anak yang berusia lebih tua, orang tua dan guru menduga adanya gangguan pada anak tersebut.

Pada penelitian ini didapatkan angka prevalensi yang berbeda - beda berdasarkan tingkatan kelas. Prevalensi untuk anak kelas 1 sebesar $16,67 \%$, kelas 3 sebesar $16,67 \%$, dan kelas 5 sebesar $66,66 \%$ sedangkan untuk kelas 2, kelas 4 , dan kelas 6 tidak didapatkan hasil yang menunjukkan adanya gejala GPPH. Pada penelitian ini didapatkan gejala GPPH lebih banyak ditunjukkan pada anak dengan tingkatan kelas lebih tinggi. Hal ini juga berbeda dengan hasil penelitian Dwidjo Saputro (2009) yang menunjukkan prevalensi pada anak kelas 1 sebesar $30,1 \%$, kelas 2 sebesar 25,3\%, kelas 3 sebesar 25,3\%, kelas 4 sebesar 25,9\%, kelas 5 sebesar $20,7 \%$, dan kelas 6 sebesar $29,7 \%$. Pada penelitian tersebut angka prevalensi GPPH pada anak kelas 1 hampir sama dengan anak kelas 6 . Adanya kondisi ini menunjukkan suatu pola gejala yang berkaitan dengan tipe gejala GPPH. Pada anak dengan tingkatan kelas yang lebih tinggi lebih sering ditemukan gejala inatensi sedangkan anak dengan tingkatan kelas yang lebih rendah lebih sering ditemukan gejala hiperaktivitas impulsivitas. $^{2}$ Adanya peningkatan gejala inatensi pada anak dengan tingkatan kelas lebih tinggi menunjukkan bahwa pada saat tersebut anak - anak dituntut untuk memiliki kemampuan fokus yang lebih baik dibandingkan ketika masih berada pada tingkatan kelas yang lebih rendah. Kebutuhan untuk belajar dan pencapaian prestasi akademik yang baik merupakan suatu tuntutan ketika berada pada tingkatan kelas yang lebih tinggi. Pada tingkatan kelas yang lebih rendah, sebagian besar anak - anak masih memiliki keinginan yang besar dalam hal bermain sehingga munculan gejala hiperaktivitas - impulsivitas lebih sering ditemukan.

Menurut kriteria diagnosis berdasarkan Diagnostic and Statistical Manual of Mental Disorder Edisi IV (DSM - IV), GPPH dibagi menjadi beberapa subtipe, yaitu tipe predominan inatensi, tipe predominan hiperaktivitas - impulsivitas, dan tipe kombinasi. ${ }^{3}$ Ketiga tipe ini memiliki prevalensi yang berbeda - beda. Berbagai penelitian mengemukakan bahwa tipe predominan hiperaktivitas - impulsivitas memiliki insiden lebih besar bila dibandingkan dengan tipe inatensi. ${ }^{2}$ Dari hasil penelitian ini didapatkan prevalensi GPPH tipe predominan hiperaktivitas impulsivitas sebesar $66,67 \%$ atau sekitar 4 dari 6 orang yang menunjukkan gejala GPPH sedangkan tipe predominan inatensi sebesar $33,33 \%$ atau sekitar 2 dari 6 orang yang menunjukkan gejala GPPH. Pada penelitian ini tidak ditemukan subtipe kombinasi.

Subtipe GPPH ini berkaitan dengan usia dan tingkatan kelas. Pada penelitian ini ditemukan bahwa 2 dari 4 anak yang menunjukkan gejala GPPH pada tingkatan kelas 5 menunjukkan gejala dominan inatensi dan anak dengan tingkatan kelas yang lebih rendah menunjukkan gejala dominan hiperaktivitas impulsivitas. Pada anak yang berusia lebih muda dan tingkatan kelas lebih rendah, tipe predominan hiperaktivitas - impulsivitas lebih banyak dibandingkan tipe lainnya. Pada anak yang berusia lebih tua dan tingkatan kelas lebih tinggi, tipe predominan inatensi lebih banyak dibandingkan tipe lainnya. Walaupun gejala hiperaktivitas - impulsivitas akan berkurang seiring pertambahan usia, tetapi gejala inatensi tidak berkurang bahkan cenderung meningkat. Hal ini diduga menjadi salah satu faktor peningkatan angka prevalensi pada anak yang berusia lebih tua dan tingkatan kelas lebih tinggi. ${ }^{2}$

\section{KESIMPULAN}

Dari hasil penelitian terhadap siswa dan siswi sekolah dasar negeri Kecamatan Padang Timur Kota Padang Tahun 2013 dapat diambil kesimpulan bahwa prevalensi Gangguan Pemusatan Perhatian dan Hiperaktivitas (GPPH) adalah $8 \%$ dengan perbandingan antara laki - laki dan perempuan $2: 1$. Prevalensi GPPH terbanyak ditunjukkan pada kategori usia 11 - 13 tahun, tingkatan kelas 5 , dan subtipe munculan terbanyak adalah subtipe predominan hiperaktivitas - impulsivitas.

\section{DAFTAR PUSTAKA}

1. Eapen V, Mabrouk AA, Zoubeidi T, Sabri S, Yousef S, Al-Ketbi J, et al. Epidemiological study of attention deficit hyperactivity disorder among school children in the United Arab Emirates. Journal of Medical Sciences. 2009; 2(3): 119-27.

2. Saputro D. ADHD (attention deficit/hyperactivity disorder). Jakarta: Sagung Seto; 2009

3. American Psychiatric Association. Diagnostic and statistical manual of mental disorders. Edisi ke-4. Washington, DC: American Psychiatric Press; 2000.

4. Singh I. Beyond polemics: science and ethics of ADHD. Nature Reviews. Neuroscience. 2008; 9 12): 957-64

5. Nair J, Ehimare U, Beitman BD, Nair SS, Lavin A. Clinical review: evidence-based diagnosis and treatment of ADHD in children. Mo Med. 2006;103(6): 617-21.

6. Kaplan HI, Sadock BJ, Greb JA. Gangguan defisit atensi. Dalam: Kaplan - Sadock Sinopsis Psikiatri IImu Pengetahuan Perilaku Psikiatri Klinis Jilid Dua. Tangerang: Binarupa Aksara Publisher; 2010. hlm.744-52.

7. Centers for Disease Control and Prevention (CDC). Increasing prevalence of parent-reported attention-deficit/hyperactivity disorder among children in United States, 2003 and 2007. MMWR. 2010; 59: 1439.

8. Pineda DA, Lopera FA, Henao GC, Palacio JD, Castellanos FX. Review of neurology. 2001; 32: 217-22.

9. Wihartono W, Sutarni S, Setyaningsih I. Faktor risiko attention deficit hyperactivity - disorder (ADHD) pada murid sekolah dasar di kecamatan Bantul D.I. Yogyakarta. Berkala Kesehatan Klinik. 2007; 13(2): 73-81.

10. Benjasuwantep B, Ruangdaraganon N, Visudhiphan P. Prevalence and clinical characteristic of attention deficit hyperactivity disorder among primary school students in Bangkok. Journal of Thailand Medical Association. 2002; 85(4):1232-40.

11. Adewuya AO, Famuyiwa OO. Attention deficit hyperactivity disorder among Nigerian primary school children: prevalence and co-morbid 
conditions. European of Child and Adolescent Psychiatry. 2007; 16(1): 10-15.

12. Waschbusch, DA, King S. Should sex-specific norms be used to assess attentiondeficit/hyperactivity disorder or oppositional defiant disorder. Journal of Consulting and Clinical Assessment. 2006: 179-85.
13. Froehlich TE, Lanphear BP, Epstein JN, Barbaresi WJ, Katusic SK, Kahn RS. Prevalence, recognition, and treatment of attentiondeficit/hyperactivity disorder in a national sample of US children. Formerly Archives of Pediatrics and Adolescent Medicine. 2007; 161(9): 857-64. 